\title{
Analysis of the disciplines of postgraduate rehabilitation programs in Brazil
}

\author{
Análise das disciplinas dos programas de \\ pós-graduação em reabilitação no Brasil
}

\section{Análisis de las asignaturas de los programas de posgrado en rehabilitación en Brasil}

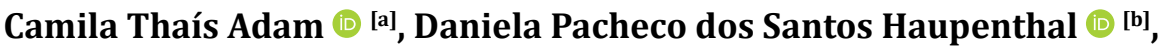

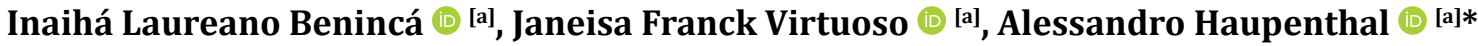

[a] Universidade Federal de Santa Catarina (UFSC), Araranguá, SC, Brazil

[b] Universidade do Extremo Sul Catrinense (Unesc), Criciúma, SC, Brazil

\begin{abstract}
Introduction: Due to the increasing number of postgraduate programs in rehabilitation science and of masters and doctoral researchers in Brazil, there has been significant improvement in the production and quality of these studies. However, this only addresses some research fields but not others, which highlights the need to show the current professional development process and discuss the role of these professionals in an interdisciplinary framework. Objective: To analyze the research lines and disciplines of Brazilians' postgraduate programs in rehabilitation science. Method: A qualitative descriptive study used the Sucupira platform and data sought from websites properly registered on Capes (Coordination for the Improvement of Higher Education Personnel). Data frequency analysis and the relation between research lines and disciplines were achieved using TextStat (Simple Text Analysis Tool), version 3.0. Results: The most
\end{abstract}

* CTA: Master's Student, e-mail: camila.adam@hotmail.com DPSH: Doctoral Student, e-mail: danielapshaupenthal@yahoo.com ILB: undergrad, e-mail: inaiha.b@gmail.com JFV: PhD, e-mail: janeisa.virtuoso@ufsc.br AH: PhD, e-mail: dedsnet@yahoo.com.br 
frequent fields of study among the postgraduate programs analyzed were neurology, cardiorespiratory, and musculoskeletal. The description of the research lines and their objectives aim the assessment or intervention for rehabilitation comprehension. Conclusion: The research lines and disciplines do not follow epistemological discussions, neither the change of concepts or paradigms necessary for the successful entry of these professionals into an interdisciplinary framework.

Keywords: Physical Therapy Specialty. Knowledge. Specialization. Knowledge Management.

\section{Resumo}

Introdução: Devido ao crescimento no número de programas de pós-graduação em ciências da reabilitação e no número de mestres e doutores, ocorreu aumento significativo da produção e da qualidade de estudos publicados. Apesar disso, há grande produção em determinadas áreas de conhecimento e escassez de produção em outras, o que ocasiona a necessidade de retratar o panorama geral da formação dos profissionais e refletir sobre a adequação ao atual mercado interdisciplinar. Objetivo: Analisar as disciplinas e as linhas de pesquisa dos programas de pós-graduação ligados às ciências da reabilitação no Brasil. Método: Este é um estudo descritivo com abordagem qualitativa a partir da análise de conteúdo. A análise foi realizada a partir de dados da plataforma Sucupira e sites dos programas cadastrados/regulares da Capes (Coordenação de Aperfeiçoamento de Pessoal de Nivel Superior). Para contabilizar a frequência das palavras e relações entre as linhas e disciplinas/ áreas de estudo, utilizou-se o programa TextStat (Simple Text Analysis Tool), versão 3.0. Resultados: Por meio das análises realizadas, percebe-se que as categorias de estudo predominantes estão relacionadas às áreas da neurologia, cardiorrespiratória e musculoesquelética. A descrição das linhas e seus objetivos visam, principalmente, a avaliação ou intervenção para o estudo da reabilitação. Conclusão: As disciplinas e as linhas de pesquisa não acompanham as discussões epistemológicas e as mudanças nos conceitos e paradigmas necessários à boa inserção do profissional no mercado interdisciplinar.

Palavras-chave: Fisioterapia. Conhecimento. Especialização. Gestão do conhecimento.

\section{Resumen}

Introducción: Debido al crecimiento del número de programas de postgrado en rehabilitación y del número de maestros y doctores, hubo un aumento significativo en la producción y calidad de los estudios publicados. A pesar de ello, hay gran producción en determinadas áreas del conocimiento y escasez de producción en otras, lo que hace necesario retratar el panorama general de la formación de profesionales y reflexionar sobre la adecuación al actual mercado interdisciplinario. Objectivo: Este es un estudio descriptivo con enfoque cualitativo para el análisis de contenido. Analizar las asignaturas y las líneas de investigación, de las carreras de posgrado en fisioterapia y ciencias de la reabilitación, en territorio Brasileño. Método: El análisis se realizó por la plataforma Sucupira y los sitios de los programas cadastrados/regulares de la Capes (Coordenação de Aperfeiçoamento de Pessoal de Nível Superior). Para contabilizar la frecuencia de palabras y relaciones entre las líneasy asignaturas/áreas de estudio, se utilizó el programa TextStat (Simple Text Analysis Tool), versión 3.0.

Resultados: Por medio de análisis realizadas, se observó que las categorías de estudio predominantes son las relacionadas con las áreas de la neurología, cardiorespiratória y musculoesquelética. La descripción de las líneas y sus objetivos es principalmente, la evaluación o intervención para los estudios de la reabilitación. Conclusión: Los resultados muestran que las asignaturas y las líneas de investigación no siguen los cuestionamientos epistemológicos y los cambios en los conceptos y paradigmas son necesarios para una buena insercción del profesional que trabaja en ámbito interdisciplinar.

Palabras clave: Fisioterapia, Conocimiento, Especializacón. Gestión del Conocimiento. 


\section{Introduction}

Because of the increasing number of postgraduate programs in rehabilitation science and the consequent rise of researchers in Brazil [1-4], there has been significant improvement in the production and quality of these studies $[1,2,5]$. This change pertains only to some research fields, whereas others have appeared infrequently in recent publications [6].

Rehabilitation science emerged from a need gap in medical practices. Thus, the body of knowledge was driven by similar and previously developed areas such as physiotherapy, medicine, occupational therapy etc. [7, 8]. Although the historical pathways of these areas were different [9], they theoretically share common disciplines such as anatomy, physiology, neurology etc. [8]. Since the development of rehabilitation science came from integration of previous knowledge, practices and theories, it is difficult to specify its final theoretical content [7]. As expected, some characteristics were inherited from this historical aspect, such as approach methods, thinking, compartmentalization, disciplines of study, and consequently, professional branches [10].

Each discipline has a unique perspective, and this outlook produces a sense of certainty around its understanding of reality and its problems. Therefore, each one has its own "lens", with which it assesses a specific dimension of the human being [11]. Most of the time on professional practice, the fragmentation and reduction of perspective remains undone [10]. This compartmentalization is a current issue in healthcare. Its approach has been changing during the last decade from an individualized, curative, and hospital-centric model that neglects universal health concepts and social sciences to a systemic and holistic one. Overcoming these barriers and achieving interdisciplinary synergies, physiotherapists are focusing on community-based healthcare [12] as a switch towards a promotive and preventive model [13], thereby aiming to exceed the limits of curative assistance [14].

An interdisciplinary approach is required to understand the complexity of the human healthdisease process [15]. Given the shift in health paradigms and a society that is looking for developing an interconnected knowledge network, the disciplinary approach tends to be transcended $[10,15,16]$.

It is reasonable to conclude that those highly educated students would be clinically rethinking and questioning professional practices. Moreover, practices could equate to the variety of realities present in the country. The expected questions about professional practice should include the following: have human compartmentalization in rehabilitation could be overcome in professional practice? Is there any concern regarding this reality? How has rehabilitation science recreated its identity and molded it into different realities found in the country? A unique study will not answer these questions; it will not even completely address these questions and their subsequently triggered responses. However, in research, asking the right question is usually more important than answering it.

This study aimed to analyze research lines and disciplines of Brazilian postgraduate programs in rehabilitation science in order to describe the current professional development process and to discuss these professional roles within an interdisciplinary framework.

\section{Methods}

This is a qualitative descriptive study. To assess the research lines and disciplines from the aforementioned programs, Sucupira platform was used and the data was sought from the websites properly registered on Capes (Coordination for the Improvement of Higher Education Personnel). In the case of insufficient information, we attempted to contact the authors by phone or email.

Initially, two authors independently identified the active programs properly registered on Capes and extracted the following: discipline's name, research line titles, and its description. Two more authors independently scanned and read the themes related to the disciplines and research lines in order to identify a keyword that could define it as a field of study. Any disagreement on the research line or discipline classification was resolved by consulting a third author.

We assessed the data frequency using TextStat (Simple Text Analysis Tool) software, version 3.0. Using the same software, we also enumerated the word frequency in a file and the relation between the research lines and disciplines.

\section{Results}

Research lines and disciplines of seventeen postgraduate programs were retrieved, fifteen from available information on websites and two by phone or email contact. Two postgraduate programs were excluded due to the lack of information. 


\section{Fields of study and research lines}

A total of 51 research lines and 61 fields of study were identified; the difference was expected as a research line may cover more than one field of study. The most frequent fields of study among the programs analyzed (Figure 1) were neurology (14), cardiorespiratory (14) and musculoskeletal (12).

We separately assessed the word appearances in the titles and descriptions of the research lines. According to Table 1, "assessment", "intervention", "process", "rehabilitation", and "physiotherapy" are the most frequently used words in the titles and descriptions of research lines.

Table 1 - Keywords counting results ordered by frequency of research lines titles and its description from postgraduate programs related to rehabilitation

\begin{tabular}{|c|c|c|c|}
\hline Research line title & n. & $\begin{array}{c}\text { Research line } \\
\text { description }\end{array}$ & n. \\
\hline Assessment & 25 & Assessment & 58 \\
\hline Intervention(s) & 20 & System(s) & 53 \\
\hline $\begin{array}{l}\text { Nervous, } \\
\text { neurofunctional, } \\
\text { neurobiological, } \\
\text { neurologic, } \\
\text { neuromuscular, } \\
\text { neuromusculoskeletal }\end{array}$ & 14 & Intervention(s) & 52 \\
\hline Process & 14 & $\begin{array}{l}\text { Nervous, neurological, } \\
\text { neurofunctional, } \\
\text { neurobiological, } \\
\text { neuromuscular, } \\
\text { neuromusculoskeletal }\end{array}$ & 38 \\
\hline Rehabilitation & 14 & Process & 37 \\
\hline System(s) & 14 & Rehabilitation & 32 \\
\hline Physiotherapy & 11 & Performance & 24 \\
\hline Performance & 10 & Different & 24 \\
\hline Functional & 9 & $\begin{array}{l}\text { Muscle, } \\
\text { musculoskeletal }\end{array}$ & 24 \\
\hline $\begin{array}{l}\text { Cardiopulmonary, } \\
\text { cardiorespiratory }\end{array}$ & 8 & Research & 23 \\
\hline Illness, dysfunctions & 7 & Health & 23 \\
\hline Musculoskeletal & 6 & Physiotherapy & 22 \\
\hline Health & 6 & Respiratory & 21 \\
\hline Adults/aged, aging & 5 & Study & 20 \\
\hline Cardiovascular & 5 & Cardiovascular, cardiac & 19 \\
\hline Respiratory & 5 & Dysfunctions & 19 \\
\hline Biologics & 4 & Investigate (ion) & 19 \\
\hline Dysfunctions & 4 & Functional & 18 \\
\hline Human & 4 & Line & 18 \\
\hline Aggravate & 3 & $\begin{array}{l}\text { Cardiorespiratory, } \\
\text { cardiopulmonary }\end{array}$ & 17 \\
\hline
\end{tabular}

Programs' disciplines

Through discipline analysis, it was found that the mean number of offered disciplines were nineteen (ranging from 12 to 39). If the master's programs were separated from the doctoral ones, we could expect the number of disciplines in doctoral programs to increase. The eight master's programs offered a mean of fifteen disciplines (ranging from 12 to 22). Meanwhile, the nine doctoral programs offered a mean of 28 disciplines (ranging from 17 to 39 ).

Among the names involved in disciplines, the word "rehabilitation" appeared the most (Table 2), followed by "topics" and "assessment" with a similar frequency. The disciplines were classified into 23 themes (Table 2). Under this classification, the most cited theme was methodology, followed by cardiorespiratory.

The word "research" was the most frequent among mandatory disciplines' names (Table 3), followed by "rehabilitation" and "methodology." These disciplines were classified into thirteen themes, which indicated the programs' concern regarding methodology, biostatistics and teaching methods or teaching internship.

Table 2 - Keywords counting results ordered by frequency of disciplines titles and their themes classification from postgraduate programs related to rehabilitation

\begin{tabular}{|c|c|c|c|}
\hline Research line title & n. & Themes classification & n. \\
\hline Rehabilitation & 66 & Methodology* & 40 \\
\hline Topics & 63 & Cardiorespiratory** & 39 \\
\hline Assessment & 59 & Health*** & 29 \\
\hline Physiotherapy & 44 & Teaching $^{\dagger}$ & 28 \\
\hline Research & 41 & Biostatistics & 27 \\
\hline $\begin{array}{l}\text { Neuro, nervous, } \\
\text { neurofunctional, } \\
\text { neuromotor, } \\
\text { neuromuscular, } \\
\text { neurorehabilitation }\end{array}$ & 37 & Seminary/topics & 25 \\
\hline Advanced & 34 & Assessment/measures & 25 \\
\hline Methods, methodology & 34 & Neurology & 23 \\
\hline Health & 30 & Biomechanics & 21 \\
\hline Teacher, teaching & 29 & Exercise physiology & 18 \\
\hline Intervention & 29 & Musculoskeletal & 15 \\
\hline Advanced & 28 & Motor control & 11 \\
\hline Science, scientific & 28 & Physiology & 11 \\
\hline Human & 25 & Dyadic & 10 \\
\hline Biostatistics & 24 & $\begin{array}{l}\text { Instrumentation/signal } \\
\text { processing }\end{array}$ & 9 \\
\hline Functional & 22 & Biology & 8 \\
\hline
\end{tabular}


(Conclusion)

\begin{tabular}{lrll}
\hline $\begin{array}{l}\text { Respiratory, pulmonary, } \\
\text { pneumology }\end{array}$ & 21 & Electrotherapy & 7 \\
Intern & 20 & $\begin{array}{l}\text { Pediatric } \\
\text { Seminary }\end{array}$ & 6 \\
$\begin{array}{l}\text { Cardiopulmonary, } \\
\text { cardiorespiratory }\end{array}$ & 18 & $\begin{array}{l}\text { Bioethics } \\
\text { practice }\end{array}$ & 6 \\
$\begin{array}{l}\text { Movement } \\
\text { Muscle, } \\
\text { musculoskeletal }\end{array}$ & 18 & Epistemology & 5 \\
Functional & 18 & Sportive & 4 \\
\hline
\end{tabular}

Note: *: 20 directly related to method, others: scientific writing, qualitative research, clinical research, experimental research planning or design; **: 22 was Cardiorespiratory, 11 linked to respiratory and 6 related to cardiology; ${ }^{\star \star *}: 29$ was Health, 15 in public health ( 6 related to epidemiology, 3 with health instrumentation and occupational health, 2 linked to health education and one directly named public health). Health of the elderly were 14 disciplines. Women's health was the subject of 6 disciplines; $\uparrow$ : Mandatory for master's and doctoral programs.

Table 3 - Results of the themes classification from mandatory disciplines offered by postgraduate programs related to rehabilitation

\begin{tabular}{lclc}
\hline Research line title & $\mathbf{n}$ & $\begin{array}{c}\text { Themes classification } \\
\text { from mandatory } \\
\text { disciplines }\end{array}$ & $\mathbf{n}$ \\
\hline Research & 16 & Methodology & 18 \\
Rehabilitation & 12 & Biostatistics & 12 \\
Methodology & 10 & Dyadic & 10 \\
Biostatistics & 10 & Teaching & 5 \\
Education & 9 & Seminary/topics & 6 \\
Superior & 8 & Assessment/measures & 3 \\
Dyadic & 6 & Epidemiology & 2 \\
Teaching & 5 & Epistemology & 2 \\
Advanced & 5 & Neurology & 2 \\
Seminary & 5 & Biomechanics & 2 \\
Scientific & 5 & Physiology & 2 \\
Functional & 4 & Evidence based on practice & 1 \\
Practice & 4 & Bioethics & 1 \\
\hline
\end{tabular}

\section{Discussion}

Analyzing the data, it was possible to observe that the most frequent fields of study of postgraduate research lines were neurology, cardiorespiratory and musculoskeletal (Figure 1).

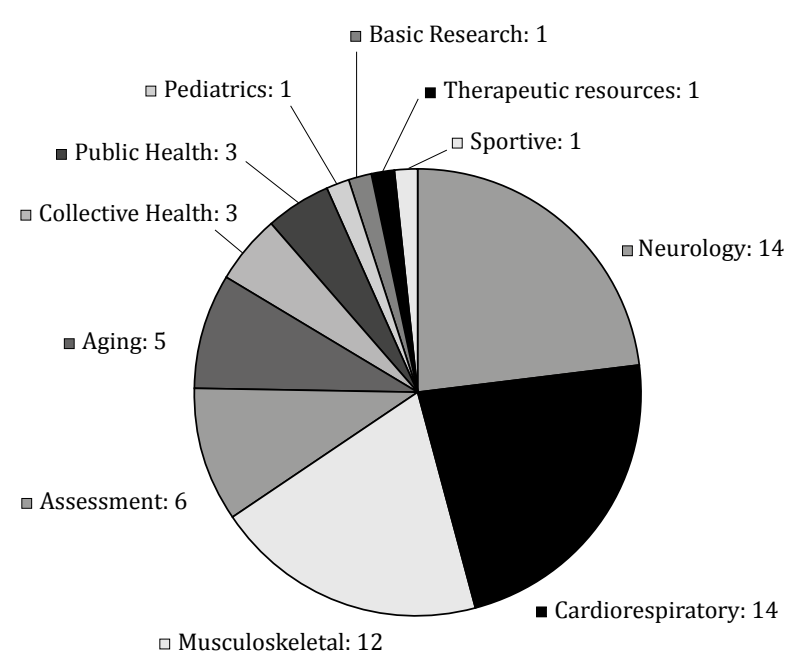

Figure 1 - Research lines classification of postgraduate programs related to rehabilitation.

In some cases, a research line covered more than one field, such as neurology and musculoskeletal or cardiorespiratory and neurology. Despite what was expected as an aim for knowledge production through a multidisciplinary approach to research problems involving different fields integration (for example, conjunct discussions), the descriptions of these research lines suggests that the purpose of this association was merely to accomplish programs' requirements. Thus, besides being described together, these fields of study remained compartmentalized. We suppose that this may be due to a lack of space or professors for separating the research lines, and it will probably change after adding more professors in the program or rearranging its research lines. Bosch [17] reminded us that the pressure of becoming researchers in a so short period often leads the programs and supervisors to neglect the wider context of scientific process in the professional development.

According to the research lines description, it was found that assessment or intervention was the main aim of rehabilitation studies (Table 1). An assessment or intervention is related to the functionality or performance of a disease or dysfunction or health. It should be remarked that one of the most frequent words was "physiotherapy". Once the analyzed programs were related to rehabilitation sciences, we must recognize the prevalence of physiotherapy approach in the assessment or intervention efficacy, especially in neurology, cardiorespiratory and musculoskeletal fields.

The increasing appearance of these three words may explain the prevalence of studies and course 
conclusion papers in these fields $[5,18]$ and, hence, the high number of publications of biomedical based studies. The biomedical model neglects patient education and promotive approach; on the other hand, it prioritizes quantitative research, denying any subjectivity that cannot be turned into numbers [19]. Therefore, disciplinary approach leads to studies that are excluded from social framework and most of the time results in a restricted perspective of science, which is incapable of solving problems and comprehending the complexity of health-disease process.

Besides, the biomedical model also neglects individual social background, limiting the promotive and preventive approach. For this reason, the Brazilian Ministry of Education and Culture (MEC) instituted the National Curricular Guidelines (DCNs) of the physiotherapy course in 2002 [20]. The guidelines proclaimed specific and general professional development, emphasizing a promotive and preventive approach as well as rehabilitation under both individual and collective levels [20]. However, this new model has not entirely been implemented. The teaching practice, with its core on a biomedical model, has been constantly implemented to the curriculum of postgraduate programs, but it frequently fails to approach the social role of physiotherapists, sociocultural factors, and epistemological construction. In addition, the current framework, in which statistical quantitative studies are overrated, discourages those assessing the historical-social background of individuals, leading to a small social concern in clinical practice.

To Higgs and Titchen [21], epistemology is the branch of philosophy that studies the types of knowledge, thereby implying that knowledge is an awareness judged to reach a certain standard regarding the paradigm (vision or epistemology) set by the author of this awareness. This interpretation leads to some disagreements in scientific literature. Some professionals consider the knowledge of different paradigms as a necessary condition to choose which best represents a physiotherapist's reality [19]. On the other hand, others think that for a clinical profession, physiotherapy must focus on the methods to develop and explain the knowledge in a clinically relevant domain [22].

According to Kuhn [23], the sciences with a wider focus on social needs are free from a single perspective. To Robertson [22], the knowledge of epistemology does not provide a means of generating empirical knowledge.
Although he believes that epistemology is irrelevant to technical knowledge production, he describes the importance of these reflections as it leads to the thinking about which directions to adopt. Thus, this discussion becomes unnecessary if we assume rehabilitation science as an applied field because it cannot assume a single paradigm. To fit into the current framework [24], epistemology and the philosophy of sciences might be considered as important tools to the physiotherapists' comprehension of their position within the sociopolitical context and the paths to forge their future. Notwithstanding, a single discipline would never be enough to approach all those issues as there is an awareness that floats around the edges and, quite often, goes furtively beyond borders without being detected.

To that extent, developed professionals should be capable of technical and lay communication across a variety of departments [17, 25-27]. Furthermore, we should ensure that professors and students are able to perform activities that were not required in the first place; for example, involvement in political, institutional, and public administration sectors engaged with social groups. In effect, these professionals could attend to particular needs of the society with technical and updated solutions for health and environmental problems; not just the new problems but also the long-established ones. In addition, disciplines related to epistemology and science's philosophy stimulate the development of critical thinkers [17, 27, 28].

Analyzing the disciplines, we observed a trend toward assessment and intervention associated with the following fields of study: neurology, cardiorespiratory and musculoskeletal (Table 2). Both obligatory and elective disciplines aim at methodological, biostatistics and pedagogical teaching. None of these mandatory disciplines approach epistemological discussions. Neither the concepts nor the paradigms necessary for the successful entry of professionals into the labor market, especially those who aim at communitybased healthcare, underwent any change.

On the discipline themes, it was also observed the appearance of "health," which comprehended a variety of thematic areas, such as epistemology and health related to work/women/collective, especially aging. The programs prepare students to perform research and teach classes. However, considering that the world is undergoing continuous change, 
we might have important implications for applied research where students discuss who they are in the current world and what the purpose of their research in this framework is. To achieve this approach, an integration of disciplines from different bodies of knowledge is required to change the conventional process of thought and production.

Studying this process, it is possible to conclude that the socialization needed for public recognition of physiotherapists and other professionals of rehabilitation sciences remain unachieved $[1,29$, 30]. Through this analysis, we see that none of the disciplines are addressing, in its totality, the social, cultural, and historical aspects of the population. From this context, as highlighted by Freire [31], we should not expect from students what they were not taught. Likewise, we should not expect them to research in fields that were out of their purview.

Social perspective must be considered for knowledge production and appropriation, but most of the time health professionals neglect this perspective, especially when they are individually focused on the patient. The social approaches studied by authors who were concerned with the future of Brazil's postgraduate programs $[1,4,5,18,32]$ remain unimplemented in the teaching process and course conclusion papers, reflecting its application to research. Perhaps, the application of this approach may be a paradigm change to the field just like when the focus shifted from incapacity to a functional idea some time ago [33].

\section{Conclusion}

After analyzing the assessed disciplines, we found a trend toward assessment/intervention, mainly related to three postgraduate fields of study: neurology, cardiorespiratory and musculoskeletal. The obligatory disciplines focus on methodology, biostatistics and pedagogical teaching. Moreover, there were research lines that covered more than one field of study; however, after analyzing its descriptions, we could assume that the approach was not multidisciplinary, suggesting compartmentalization in the process. Because of the predominant description characteristics of research lines and disciplines offered to postgraduate students, the paradigm change that took place in rehabilitation field remains distant from the students who aim to continue their education in Brazil.

\section{References}

1. Dantas F. Responsabilidade social e pós-graduação no Brasil : idéias para (avali)ação. Rev Bras Pos Grad. 2004;1(2):160-72.

2. Coury H, Vilella I. Perfil do pesquisador fisioterapeuta brasileiro. Rev Bras Fisioter. 2009;13(4):356-63.

3. Marsiglia RMG, Spinelli SP, Lopes MF, Silva TCP. Das ciências sociais para as ciências sociais em saúde: a produção científica de pós-graduação em ciências sociais. Cien Saude Colet. 2003;8(1):275-85.

4. Guimarães R. 0 futuro da pós-graduação: avaliando a avaliação. Rev Bras Pos Grad. 2007;4(8):282-92.

5. Virtuoso JF, Haupenthal A, Pereira ND, Martins CP, Knabben RJ, Andrade A. A produção de conhecimento em fisioterapia: análise de periódicos nacionais $(1996$ a 2009). Fisioter Mov. 2011;24(1):173-80.

6. Moral-Munoz J, Arroyo-Morales M, Herrera-Viedma E, Cobo MJ. An overview of thematic evolution of physical therapy research area from 1951 to 2013. Front Res Metr Anal. 2018;13:1-12.

7. Conti AA. Western medical rehabilitation through time : a historical and epistemological review. Sci World J. 2014;2014:432506.

8. Siegert R, McPherson K., Dean S. Theory development and a science of rehabilitation. Disabil Rehabil. 2005;27(24):1493-501.

9. Peseta T, Fortune T, Jones A, Barradel S, Kennedy-Jones M. Returning history to the educational formation of health professionals in Australia. Teach High Educ. 2017;23(1):17-29.

10. Morin E, Pena-Vega A, Paillard B. Diálogo sobre o conhecimento. São Paulo: Cortez; 2004.

11. Pink S, Waterson P, Dainty A, Cheyne A, Haslam R, Gibb $A$, et al. Interdisciplinary research for occupational safety and health knowledge. Policy and Practice in Health and Safety. 2016;14(1):22-33.

12. Bispo JP Jr. Fisioterapia e saúde coletiva reflexões, fundamentos e desafios. São Paulo: Hucitec; 2013. 
13. Bispo JP Jr. Formação em fisioterapia no Brasil: reflexões sobre a expansão do ensino e os modelos de formação. Hist Cienc Saude-Manguinhos. 2009;16(3):655-68.

14. Aweto HA, Oligbo CN, Fapojuwo OA, Olawale OA. Knowledge, attitude and practice of physiotherapists towards promotion of physically active lifestyles in patient management. BMC Health Serv Res. 2013;13:21.

15. Slatin C, Galizzi M, Melillo KD, Mawn B. Conducting interdisciplinary research to promote healthy and safe employment in health care: promises and pitfalls. Public Health Rep. 2004;119(1):60-72.

16. Erdmann A, Schlindwien B, Sousa F. Knowledge production: a dialogue among different knowledge. Rev Bras Enferm. 2006;59(4):560-4.

17. Bosch G. Train PhD students to be thinkers not just specialists. Nature. 2018;554:277.

18. Haupenthal A, Virtuoso J, Duarte N, Santos DP, Andrade A. Análise epistemológica dos estudos de conclusão de curso nos programas de Pós-Graduação com Doutorado do Brasil. Fisioter Mov. 2012;25(1):141-51.

19. Bosi M. Pesquisa qualitativa em saúde coletiva: panorama e desafios. Cien Saude Colet. 2012;17(3):575-86.

20. Brasil. Resolução CNE/CES 4, de 19 de fevereiro de 2002. Diário Oficial da União. 2002 Mar 4;1:11.

21. Higgs J, Titchen A. The nature, generation and verification of knowledge. Physiotherapy. 1995;81(9):521-30.

22. Robertson VJ. Epistemology, private knowledge, and the real problems in physiotherapy. Physiotherapy. 1996;82(9):534-9.

23. Kuhn T. A estrutura das revoluções científicas. 9th ed. São Paulo: Perspectiva; 2009.

24. Shaw J, DeForge R. Physiotherapy as bricolage: theorizing expert practice. Physiother Theory Pract. 2012;28(6):420-7.
25. Trindade J, Prigenzi L. Instituições universitárias e produção do conhecimento. São Paulo Perspect. 2002;16(4):9-14.

26. Werneck VR. Sobre o processo de construção do conhecimento : o papel do ensino e da pesquisa. Ensaio: Aval Pol Publ Educ. 2006;14(51):173-96.

27. Dunne G. Beyond critical thinking to critical being : criticality in higher education and life. Int J Educ Res. 2015;71:86-99.

28. Nixon SA, Yeung E, Shaw JA, Kuper A, Gibson BE. Seven-step framework for critical analysis and its application in the field of physical therapy. Phys Ther. 2017;97(2):249-57.

29. Nascimento M, Sampaio R, Salmela J, Mancini MC, Figueiredo IM. A profissionalização da fisioterapia em Minas Gerais. Rev Bras Fisioter. 2006;10(2):241-7.

30. Sparkes V. Profession and professionalisation part 1: role and identity of undergraduate physiotherapy educators and part 2: professionalism within academia. Physiotherapy. 2002;88(8):481-92.

31. Freire P. Pedagogia do oprimido. 49th ed. Rio de Janeiro: Paz e Terra; 2005.

32. Lopes Neto S, Bevilaqua L, Fischer T, Marcovitch J, Almeida VJF, Nunes EO. Mestrado no Brasil: a situação e uma nova perspectiva. Rev Bras Pos Grad. 2005;2(4):139-44.

33. Jette A. Outcomes research : shifting the dominant research paradigm in physical therapy. Phys Ther. 1995;75(11):965-70. 